\title{
One-Substitution and Noun Ellipsis in English and Danish
}

\author{
Maria Mørch Dahl 8
}

\section{Introduction}

In English as well as Danish, a noun in a determiner phrase can be elided, creating an elliptical noun phrase that is filled by an anaphoric noun (i.e. a noun that refers to an earlier word or phrase in the same context) which is lexically empty, either overt, for example as one, or silent, that is, it is left out. When the anaphoric noun is overt, the English phenomenon is usually referred to as one-substitution, which is a term that may be adopted for the description of the equivalent phenomenon in Danish. One-substitution is very common in English but seems infrequent in Danish. These are the main points from the generalizations concerning one-substitution in Danish as outlined in section 4:

1. Danish has an indefiniteness restriction.

2. Danish does have a plural empty noun equivalent to the English ones.

3. Danish has an overt empty noncount noun, whereas English does not.

A summary of the generalizations concerning one-substitution in Danish and a comparison with English are found in tables (28) and (29) in section 6.

Based on a comparison of elliptical NPs in English and German, Günther $(2018,48)$ argues that the possibility of one-substitution has to do with the inflectional properties of a language. The generalizations concerning one-substitution in Danish supports this argument, because Danish uses onesubstitution more than German (Danish has less inflection than German), but less than English (Danish has more inflection than English).

\section{One-substitution}

One-substitution is the phenomenon where a noun phrase is substituted by the count noun one. One has no lexical meaning but receives interpretation from its antecedent, for example drink in (1) and ord "word" in (2).

Leviathan: Interdisciplinary Journal in English (ISSN: 2446-3981), No. 4, 2019.

(C) The Journal Editors 2018 
(1) a. Yes, I'd like a $\underline{\text { drink, }}$, but just a small one.

b. I thought you preferred large ones. (Quirk et al. 1985, 387)

(2) ... lægge bogstaverne sammen, så de danner et ord og helst et langt et. (KorpusDK) ... put the letters together, so they form a word and preferably a long one.

In English, one can be used as a substitute for count nouns, whereas for noncount nouns, such as wine, the noun in question is simply left out (which is signalled here by writing ec, for empy category):

(3) I prefer white wine to red $\underline{e c}$ and I sometimes keep a bottle of champagne in the fridge ready for any impromptu celebrations. (BNC)

The construction in example (3) where the noun is substituted by ec is an instance of noun ellipsis. The similarity between the construction in (3) where the anaphoric noun is silent and the construction in (1) where the anaphoric noun is realised as one/ones suggests that both constructions are examples of noun ellipsis. Thus, "anaphoric one is considered the overt counterpart of a silent anaphoric noun" (Günther 2018, 45). Also in Danish, there is both an overt variant, as in (2) above, and a silent variant, as in (4), of the empty noun in elliptical NPs:

(4) Deres ønske om at udskifte det tidligere trofaste teenagerpublikum med et voksent $\underline{e c}$ skal måske nok lykkes på længere sigt. (KorpusDK)

Their wish to replace the previous loyal teenage audience with a grown-up may maybe arguably succeed in the longer term.

Hansen and Heltoft $(2011,546)$ state that one-substititon in Danish can occur "when there is also a preceding adjective", which is true for both the Danish and the English examples in (1)-(4). It is this type of construction, namely a DP with an attributive adjective and an elliptical NP, which will be used for the comparison of one-substitution in English and Danish in this paper.

Some elliptical NPs do not have an antecedent (i.e. what they refer to is not an earlier word or phrase), and the empty noun (overt or silent) is therefore not really anaphoric but seems to refer to 
something abstract or undefined by the linguistic context. The main focus of this paper, however, is on overt and silent anaphoric nouns, i.e. cases of one and ec that do have antecedents.

\section{The overt anaphoric empty noun}

Whereas the silent anaphoric noun is simply labelled $e c$, as already seen, the overt variant is found in different forms, both in English and in Danish.

\subsection{English one/ones}

As seen in (1), one/ones is the English overt variant of the anaphoric empty noun in elliptical NPs, which occurs both in the singular (one) and in the plural (ones). This distinguishes [ $\mathrm{N}^{\circ}$ one] from [ $\mathrm{D}^{\circ}$ one] because the determiner one does not occur in the plural:

(5) a. That was one good thing about the Americans. (BNC)

b. Clearly, the starting point has been the study of wild horses. (BNC)

c. * Clearly, the starting point has been the study of ones wild horses.

The asterisk in (5)c. indicates that the use of ones as a plural determiner does not yield a grammatical sentence. The one that is used in one-substitution is [ $\mathrm{N}^{\circ}$ one], which is a lexically empty noun.

The most important grammatical feature of [ $\mathrm{N}^{\circ}$ one] is its countability. Günther $(2018,42)$ notes that one "is used to express countability in elliptical NPs with adjectives, since the latter do not carry this feature". This means that one rather than $e c$ is used when the antecedent is a count noun, whereas noncount antecedents generally require $e c$, and one cannot be inserted, as in (3), repeated as (8) with the insertion of one/ones:

(6) I prefer white wine to red (*one/*ones) and I sometimes keep a bottle of champagne in the fridge ready for any impromptu celebrations. (adapted from BNC)

The asterisks in (6) indicate that insertion of neither one nor ones as the empty noun yield a grammatical sentence. 


\subsection{Danish en/et, nogle, noget}

The overt anaphoric noun in Danish elliptical NPs is found in three distinct forms: a singular, a plural, and a noncount form.

The singular form is inflected for gender, according to the noun: $e n$ is common gender and $e t$ is neuter gender. In (7), the antecedent of en is computer which has common gender, and in (8) the antecedent of et is bogstav "letter" which has neuter gender. A similar distinction is not found in English since it does not have gender inflection in nouns.

(7) Vi kan formidle kontakt til en gruppe, der ellers aldrig ville have fundet på at købe en computer, i al fald ikke andet end en billig en på udsalg. (KorpusDK)

We can arrange contact to a group, that otherwise never would have found out to buy a computer, anyway not anything but a cheap one on sale.

(8) ... lægge bogstaverne sammen, så de danner et ord og helst et langt et. (=(2), KorpusDK) ... put the letters together, so that they form a word and preferably a lone one.

In English, the plural form of one is formed by adding the inflectional morpheme $-s$ which makes ones. A similar strategy in Danish would be to add -er, -e, or zero to en/et. None of these result in a possible plural form of the noun:
a. * Bilerne er også nogle rigtig flotte en-er.
b. * Bilerne er også nogle rigtig flotte en-e.
c. * Bilerne er også nogle rigtig flotte en. (adapted from KorpusDK)
The cars are also some very good-looking ones.

Instead, the plural form of the empty noun is nogle:

(10) Bilerne er også nogle rigtig flotte nogle. (KorpusDK)

The cars are also some really good-looking ones.

Unlike English, Danish does have an overt form of the noncount empty noun, namely noget: 
(11) Det er noget besynderligt noget, det der med når nogen, man holder af, dør. (KorpusDK) It is some odd something, that there with when someone, you care about, dies.

As in (11), noget is most common in the constructions that yield an abstract interpretation, which will be discussed briefly in sections 4.2 and 4.3 .

\section{Generalizations concerning one-substitution in Danish}

After having compared elliptical NPs in English and German, Günther (2018, 48) concludes that "it is evident that the differences seen between English and German nounless NPs relate to the languages' inflectional properties". In English, the formal feature number which is not visible on the attributive adjective can become visible on the anaphoric empty noun by insertion of one which then makes noun ellipsis possible. Günther implies that German elliptical NPs generally do not require an overt anaphoric empty noun, because "German has a rich inflectional system, expressing case, number and gender on the noun and the elements that agree with it (determiners and adjectives)" (Günther 2018, 7), thus rendering a lexically empty noun expressing the inflectional features of the elided noun unnecessary. The following outline of the generalizations concerning one-substitution in Danish will serve to investigate the role of inflectional properties in relation to the possibility and requirement of one-substitution.

\subsection{The indefiniteness restriction}

Firstly, indefiniteness seems to be required for insertion of an overt anaphoric empty noun, such as en, to be inserted. Thus, example (12) with the indefinite construction en billig en "a cheap one" is perfectly acceptable with the insertion of en, whereas example (13) with the definite construction den traditionelle "the traditional" becomes unacceptable if $e n$ is inserted rather than the silent $e c$.

(12) Vi kan formidle kontakt til en gruppe, der ellers aldrig ville have fundet på at købe en computer, $i$ al fald ikke andet end en billig en på udsalg. (=(7), KorpusDK)

We can arrange contact to a group that otherwise would never have thought to buy a computer, at least not anything but a cheap one on sale. 
(13) Erik Clausen lover seerne en anderledes opera-transmission end den traditionelle (*en), hvor scenen bliver oplyst som et andet badeværelse og nogle kameraer farter frem og tilbage. (adapted from KorpusDK)

Erik Clausen promises the viewers a different opera-transmission than the traditional (*one), where the stage is lit up like some bathroom and some cameras pace forth and back.

The asterisk in (13) indicates that the insertion of en, although being the appropriate form (agreeing with the antecedent opera-transmission in number and gender), is not acceptable, and the preferred form (which is the original sentence from the corpus) is the construction where the silent empty noun, $e c$, follows the attributive adjective traditionelle: "traditional".

However, although a rare phenomenon, it seems that the singular definite elliptical NPs can be used with the overt empty noun en in informal Danish:

(14) På den måde fik jeg udnyttet DAC’en i apollo’en og omgik den grimme en i receiveren. (http:/ /hifi4all.dk/forum/forum_posts.asp?TID=95026\&PN=3\&TPN=4)

In that way I made use of the DAC in the apollo and go around the ugly one in the receiver.

Not all native Danish speakers, however, find example (14) acceptable. This finding agrees with the notion that the construction is rare.

The indefiniteness restriction that seems prevalent in Danish one-substitution does not go both ways. While it seems that indefiniteness is a requirement for the insertion of overt empty nouns such as $e n$, not all elliptical NPs that are indefinite require an overt empty noun.

(15) Der er ofte høgeugler på vinterbesøg i den sydlige del af Sverige, og i de senere år er det sket, at en enkelt $\underline{e c}$ er smuttet over Øresund, men sjældent i større antal. (KorpusDK)

There are often hawk owls on winter visits in the southern part of Sweden and in recent years it has happened that a single has popped over Oresund, but rarely in in larger numbers.

The indefiniteness restriction is true for singular as well as plural constructions. The restriction is not absolute, however, and it seems that the plural constructions allow more easily for the insertion of an overt empty noun than the singular ones (see section 4.2). 


\subsection{The English plural empty noun ones has the Danish equivalent nogle}

As described in section 3.2 and shown in examples (9) and (10) in particular, the plural form of the overt anaphoric empty noun in Danish is nogle, whereas the English form is ones. However, nogle cannot be inserted in all types of constructions the same way ones can in English.

In the indefinite constructions, it seems that the insertion of nogle requires that the determiner in the DP is the homophone nogle:

(16) Og urene, siger den unge, vil du også smide dem væk. Der var nogle dyre nogle imellem. (KorpusDK)

And the watches, says the young, will you also throw them away. There were some expensive ones between.

In indefinite plural constructions without an indefinite determiner, insertion of nogle is not possible:

... jeg havde ikke haft køer i dag, hvis der ikke var sket noget. Han var tvunget til selv at gå foran, og gjorde sig også gældende med treracekrydsninger af røde danske (*nogle), amerikansk brunkvæg og røde canadiske (*nogle). (adapted from KorpusDK)

... I had not had cows today, if nothing had happened. He himself was forced to go in front, and also made himself effective with three-way crossing of red Danish (*ones), American brown cattle and red Canadian (*ones).

In spite of the indefiniteness restriction which generally holds for both singular and plural constructions, it seems that there is a tendency for it to be more acceptable in plural constructions. A certain type of construction with the demonstrative de der "those" seems to occur quite frequently with the overt empty noun nogle. Nogle is generally pronounced the same way as nogen, which is reflected in the spelling in (18), although the use of the demonstrative de der, which is plural, makes it is clear that nogen is to be interpreted as plural.

(18) Jeg troede ellers, at man sov i træerne, så man kunne springe ned på de der bløde nogen, der kører ude på de der sorte nogen, når det er morgen. (KorpusDK)

But I thought that one slept in the trees so one could jump down on those soft ones that drive out on those black ones when it is morning. 
The construction with nogle as the empty noun in the elliptical NP is very common when the empty noun does not have an antecedent, for which reason it receives an abstract interpretation. It is, however, also quite common in informal Danish to use nogle anaphorically as in (19):

(19) Som noget nyt i år sælges der pandekager! - Ja, der er tale om de der store nogle, - ligesom på festival og i Paris. (http://memette78.dk/mit-favoritspisested/)

As something new this year are sold there pancakes! Yes, there is talk about those big ones, - just like on festival and in Paris.

The use of nogle anaphorically with a lexically meaningful antecedent is fairly common and accepted by most native Danish speakers.

In plural constructions in informal Danish, the indefiniteness restriction seems to be even less prominent. Here, the construction also occurs with the simple definite article de "the":

(20) Hej, Er der nogen der ved hvor jeg kan finde et lækkert strikket baby navnetæppe. Indtil videre har jeg kun fundet de grimme nogle fra Ikast Etiket som alle har.

(https://www.sol.dk/debat/navnet\%C3\%A6ppe)

$H i$, is there anyone that knows where I can find a nice knitted baby name blanket. So far I have only found the ugly ones from Ikast Etiket that everyone has.

Note, though, that not all native Danish speakers find example (20) acceptable.

The standard construction for plural definite elliptical NPs in Danish is one where the anaphoric empty noun is silent:

(21) Det er de samme urter, der skal bruges i sildelagen og i den italienske salat til kyllingen, så alle de "skæve" stykker går i lagen, mens de pæne $\underline{e c}$ bruges til salaten... (KorpusDK) It is the same herbs, that will be used in the herring brine and in the Italian salad for the chicken, so all the "crooked" pieces go in the brine, while the good-looking ec are used for the salad...

As mentioned in section 4.1, this indefinite restriction is true for plural as well as singular constructions. 


\subsection{Danish has an overt empty noncount noun: noget}

As described in section 3.2 with example (11), Danish has an overt empty noun that can occur in the place of a noncount noun, whereas English does not. The noncount empty noun constructions in English use a silent noun, $e c$, but in Danish, the overt noget can be used. The most common construction of this type is one where the empty noun noget does not have an antecedent and therefore receives an abstract interpretation. In (22), the empty noun noget has the silent antecedent ec following ubehageligt "unpleasant", both of which are lexically empty nouns.

(22) Få bind for øjnene og stikke hånden ned i en pose med noget ubehageligt $\underline{e c}$, man skulle gætte, hvad var. Og som så slet ikke var noget farligt, men bare noget ganske almindeligt noget. (KorpusDK)

Be blindfolded and put your hand in a bag with something unpleasant you had to guess what was. And that then was not anything dangerous, but just some very ordinary something.

In some examples from informal Danish, the insertion of the lexically empty noget does refer to a lexically meaningful antecedent:

(23) Jeg har flere gange været glad for at det meste af Livas undertøj er noget billigt noget. (https://www.baby.dk/debat/47512pi1/navlestrengen/satme-billigt.aspx)

I have multiple times been happy for that the most of Liva's underwear is some cheap some.

The use of noget as an anaphoric noun for a lexically meaningful antecedent is not used very frequently, but it is nonetheless accepted by most native Danish speakers. No examples of the type were found in the corpus of written Danish, KorpusDK.

When there is an antecedent which is lexically meaningful, the elliptical NPs with an overt noncount antecedent generally use the silent anaphoric empty noun, $e c$, as in (24) where the antecedent of the empty noun is the noncount noun vin "wine".

(24) Eksempelvis italiensk vin blandet med noget tysk 뜨. Så har vinen fået tysk status. (KorpusDK) For example Italian wine mixed with some German. Then the wine has received German status. 
As with the noget in (22), which received an abstract interpretation because the empty noun did not refer to anything specific, an inserted noget after tysk (see (25)) will not yield the interpretation that noget refers to the antecedent vin "wine".

(25) Eksempelvis italiensk vin blandet med noget tysk noget. Så har vinen fået tysk status. (adapted from KorpusDK)

For example Italian wine mixed with some German something. Then the wine has received German status.

Instead, noget will be interpreted as referring to something more abstract or undefined, just as in (23). This example supports the idea that noget is mostly used when the intended interpretation is that the empty noun does not refer to anything specific.

As with the count nouns, described in sections 4.1 and 4.2, it is clear that the indefinite elliptical NP allows for insertion of an overt empty noun, also in constructions with a noncount noun. Although less frequent, definite noncount constructions do also seem to allow for insertion of the overt empty noun noget, at least in informal Danish:

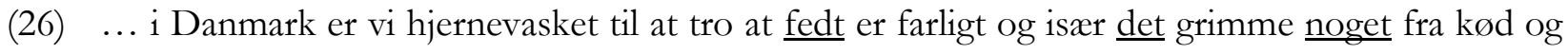
mælk- mens plantefedt uanset kilde er åh så sundt. (https:// fede-tider.blogspot.com/2010/01/uge-3-og-lidt-tanker-om-olier-og-fedt.html) ... in Denmark are we brainwashed to believing that fat is dangerous and especially the nasty stuff from meat and milk - while vegetable fat regardless of source is oh so bealthy.

Informal as it is, not all native Danish speakers find (26) acceptable. In the definite noncount as well as the countable constructions, however, it is far more common to use the silent empty noun:

(27) Forkert mad er stort set alt det fede $\underline{e c}$ og alt det søde $\underline{e}$. . (KorpusDK) Wrong food er by and large all the fat and all the sweet.

In summary, the noncount constructions seem to have a similar distribution of possibility of insertion of noget to that of countable nouns with $\mathrm{en} / \mathrm{et} / \mathrm{nogle}$, and are also affected by the indefiniteness restriction. 


\section{Danish has more inflection than English, less than German}

The generalizations concerning one-substitution in Danish seem to fit the observation that the requirement for one-substitution has to do with the inflectional properties of a language. For English as well as German, it seems clear that the need for the overt empty count noun one in English in elliptical NPs and the lack thereof in German can be attributed to the inflectional properties of the languages. Whereas English has relatively little inflection, for example no grammatical gender, German is heavily inflected. It seems clear that elliptical NPs in a language with heavy inflection do not require an overt empty noun, whereas the same construction in a language with little inflection requires the overt empty noun more often. Therefore, since Danish has more inflection than English, but less than German, one-substitution is used more frequently in Danish than in German, but not as frequently as in English. Thus, the differences between the three languages could still have something to do with the inflectional properties of the languages, as suggested by Günther $(2018,48)$.

\section{Conclusion}

For one-substitution in Danish, indefinite constructions are generally more acceptable than definite ones, but insertion of an overt empty noun in definite constructions is generally not absolutely impossible, neither in count nor in noncount constructions. These conclusions are summarized and compared with the English counterparts in (28) and (29), with reference to the examples they come from. The examples that are marked with ${ }^{\text {? }}$ are informal ones that have not been found in the corpus of written Danish, KorpusDK. They are not accepted by all native Danish speakers.

\begin{tabular}{|c|c|c|}
\hline (28) & English & Danish \\
\hline \multirow{2}{*}{$\begin{array}{l}\text { Indefinite, } \\
\text { count, singular }\end{array}$} & a small one (1)a & en billig en (7) "a cheap one" \\
\hline & ${ }^{*}$ a small ec & en enkelt ec (15) "a single $e c$ " \\
\hline \multirow[t]{2}{*}{$\begin{array}{l}\text { Indefinite, } \\
\text { count, plural }\end{array}$} & large ones (1)b & $\begin{array}{l}\text { nogle dyre nogle (16) } \\
\text { "some expensive ones" }\end{array}$ \\
\hline & *small ec & rode danske ec (17) "red Danish ec" \\
\hline \multirow[t]{2}{*}{$\begin{array}{l}\text { Indefinite, } \\
\text { noncount }\end{array}$} & *red one/ones & $\begin{array}{l}\text { noget billigt noget }(23) \\
\text { "some cheap something" }\end{array}$ \\
\hline & red ec (3) & noget tysk ec (24) "some German ec" \\
\hline
\end{tabular}




\begin{tabular}{|c|c|c|}
\hline (29) & & \\
\hline \multirow{2}{*}{$\begin{array}{l}\text { Definite, } \\
\text { count, singular }\end{array}$} & the small one & "den grimme en (14) "the ugly one" \\
\hline & *the small ec & den traditionelle ec (13) "the traditional $e c "$ \\
\hline \multirow{2}{*}{$\begin{array}{l}\text { Definite, } \\
\text { count, plural }\end{array}$} & the small ones & ?de grimme nogle (20) "the ugly ones" \\
\hline & *the small ec & de pane ec (21) "the nice $e c$ " \\
\hline \multirow{2}{*}{$\begin{array}{l}\text { Definite, } \\
\text { noncount }\end{array}$} & *the red one/ones & "det grimme noget (26) "the ugly something" \\
\hline & the red ec & $\begin{array}{l}\text { det sode ec (27) } \\
\text { "the sweet } e c "\end{array}$ \\
\hline
\end{tabular}

In (28) and (29), the countable constructions with a silent empty noun in English are marked as impossible (with an asterisk), although examples of the type of construction do exist. The reasons for this marking is, firstly, that the possibility of one-substitution, in addition to the regularities outlined here, depend on the semantics of the attributive adjective (see Günther 2018). Secondly, the summary in the tables are based on the anaphoric elliptical NPs, that is, empty nouns with an antecedent.

The pattern for one-substitution in English that emerges from tables (28)-(29) is that the possibility of one-substitution has the same distribution in indefinite and definite constructions; there is no indefiniteness restriction in English one-substitution. Instead, English seems to have a countability restriction, since all of the countable constructions have the same distribution (one is possible, ec is not), whereas the noncount constructions have the opposite distribution (ec is possible, one is not). The pattern for Danish that emerges is that there is a fairly clear distinction between the distribution in indefinite as opposed to definite constructions; the indefiniteness restriction (en is much better as indefinite, (28), than as definite, (29)). Contrary to English, Danish does not have a countability restriction, but seems to allow equally for one-substitution regardless of countability; the same distribution holds for countable and noncount constructions.

From these generalizations concerning one-substitution in Danish, it seems that there are clear tendencies as to when one-substitution is possible, such as the indefiniteness restriction, but it seems less clear when it is required. For example, in the count singular indefinite it seems possible to construct an elliptical NP both with an overt and a silent empty noun. Thus, it seems that the inflectional properties of Danish do not straightforwardly account for the possibility of insertion of an overt anaphoric empty noun such as en/et, nogle, and noget. 


\section{Further perspectives}

Although the generalizations concerning one-substitution in Danish outlined in this paper present an overview on the possibility for one-insertion in elliptical NPs, further research is required to establish the generalizations concerning when one-insertion is possible, when it is required and ec would be ungrammatical, and when it is optional.

An additional point of further research would be to investigate acceptability judgments concerning the constructions that are not accepted by all native Danish speakers. To what extent do speakers of Danish generally accept these constructions, and do the speakers that accept these constructions belong to a certain speech community? 


\section{Reference list}

British National Corpus (BNC): https://corpus.byu.edu/bnc/.

Günther, Christine. 2018. "The rich, the poor, the obvious: Arguing for an ellipsis analysis of 'adjectives used as nouns"'. Linguistics Today 246: 77-112. https://doi.org/10.1075/la.246.04gun.

Hansen, Erik, and Lars Heltoft. 2011. Grammatik over det danske sprog, edited by Torben Christiansen. Copenhagen: Det Danske Sprog- og Litteraturselskab.

KorpusDK: https://ordnet.dk/korpusdk.

Quirk, Randolph, Sidney Greenbaum, Geoffrey Leech, and Jan Svartvik. 1985. A comprehensive grammar of the English language. London: Longman. 